\title{
FACTORS AFFECTING NON-PERFORMING LOANS OF CONVENTIONAL BANKING: EVIDENCE IN INDONESIA STOCK EXCHANGE
}

\author{
Hanna Khoirunisa, Cyntia Monalisa Hutauruk, Susy Muchtar \\ Trisakti University, Indonesia \\ Email: hannakhoirunisa@gmail.com, cyntiamonalisa@gmail.com, susy.muchtar@gmail.com
}

\begin{tabular}{|c|c|}
\hline ARTICLE INFO & BSTRACT \\
\hline $\begin{array}{l}\text { Received } \\
\text { January, } 32022 \\
\text { Revised } \\
\text { January, } 102022 \\
\text { Approved } \\
\text { January, } 202022 \\
\text { Keywords: } \\
\text { Bank Capital; Bank } \\
\text { Efficiency; Income } \\
\text { Diversification; Non- } \\
\text { Performing } \\
\text { Loans (NPL); Return } \\
\text { on Assets (ROA). }\end{array}$ & $\begin{array}{l}\text { Majority banks in Indonesia still use loans as the main income to } \\
\text { finance their operations. The effects of the NPL will result in dividend } \\
\text { payments, high-interest rates and low investment rates resulting in the } \\
\text { lower economic development of the country. Based on this, this study } \\
\text { was conducted to find out the factors that affect the risk of problematic } \\
\text { credit. In this study, the authors used quantitative methods. The } \\
\text { independent variables in the study were Return on Assets (ROA), } \\
\text { Income Diversification, Bank Capital and Bank Efficiency while the } \\
\text { dependent variables were Non-Performing Loans (NPL). The study } \\
\text { collected data from } 35 \text { banking companies listed on the Indonesia } \\
\text { Stock Exchange over } 5 \text { years (2016-2020) and used the panel's data } \\
\text { regression model for its testing. Findings from this study suggest that } \\
\text { Return on Assets (ROA), Bank Capital and Bank Efficiency have a } \\
\text { significant negative effect on Non-Performing Loans (NPLs). Income } \\
\text { Diversification has no significant effect on non-performing loans } \\
\text { (NPLs). The results of this study can be used to present a successful } \\
\text { model for banking companies in Indonesia to pay more attention to the } \\
\text { mitigation of bad credit risk. All studies have used IBM SPSS } 25 \text { as an } \\
\text { analysis tool. The conclusions of the results of the study that can be } \\
\text { taken are as follows Return on Assets, Bank Capital, and Bank } \\
\text { Efficiency have a negative influence on Non-Performing Loans while } \\
\text { Income Diversification does not influence Non-Performing Loans }\end{array}$ \\
\hline
\end{tabular}

\section{Introduction}

The financial crisis is one of the most pressing and important issues for the banking sector globally. Most banks in Indonesia still use loans as the main income to finance their operations. Not all loans that are disbursed are risk-free, some loans have considerable risks and can threaten the health of the bank. In the lending business, banks are faced with defaults by loan borrowers who produce NPLs. NonPerforming Loans (NPL) create problems for the balance sheet of the banking sector on the asset side and negatively impact the income statement as a result of the provision of loan losses. The International Monetary Fund (IMF) states that loans will be considered NPLs if they do not generate interest and principal amounts for a minimum of 90 days. The main reasons for high NPL are weak credit procedures, low-skilled credit specialists, high markup spreads, low credit principles and a lack of borrower monitoring policies. NonPerforming Loans (NPLs) are a leading indicator for measuring credit risk affecting a country's banking system. (Khan et al., 2020) stressed that NPL can be used as an indicator of the banking crisis as it affects the nation's economic growth by reducing credit

$\begin{array}{ll}\text { How to cite: } & \text { Khoirunisa, H., Hutauruk, C. M., \& Muchtar, S. (2022) Factors Affecting Non-Performing Loans of } \\ & \text { Conventional Banking: Evidence in Indonesia Stock Exchange. Jurnal Syntax Ttansformation, 3(1). } \\ & \text { https://doi.org/10.46799/jst.v3i1.494 } \\ \text { E-ISSN: } & 2721-2769 \\ \text { Published by: } & \text { Ridwan Institute }\end{array}$


development (Ivanović, 2016). A low NPL level indicates a strong monetary system while a high NPL indicates a weak financial position. The increasing NPL shift will affect banking efficiency resulting in the banking crisis (Vouldis \& Louzis, 2018). Non-Performing Loans (NPLs) will block interest income, reduce investment openings and develop liquidity crises in the financial system, resulting in bankruptcy problems and a weak economic system. Thus, it is necessary to identify the factors that affect NPL and lower NPL levels for financial stability and economic objectives. Non-Performing Loans (NPLs) affect the overall routine of the banking sector, thus threatening the bankruptcy of the banking sector. High NPL levels directly affect the bank's overall financial performance (Khan et al., 2020).

Based on the background described above and previous research conducted by (Khan et al., 2020) in Pakistan in 2020 shows the influence of Return on Assets (ROA), Income Diversification, Bank Capital and Bank Efficiency on Non-Performing Loans (NPL), researchers are interested in reresearching in Indonesia. Therefore, this study is titled " Factors Affecting Non-Performing Loans of Conventional Banking: Evidence in Indonesia Stock Exchange"

1. Non-Performing Loans

Non-Performing Loans (NPLs) are financial ratios related to credit risk. Credit risk is the risk of possible bank losses as a result of not repaid credit given by the bank to debtors (Kusaly et al., 2017).

Persistently high NPL levels limit credit and economic activity in the region and increase banks' vulnerability to shocks. High NPLs have a negative impact on a bank's profitability, given that they require banks to increase the provision and usually do not generate revenue. High NPLs also increase banks' vulnerability to shocks by reducing their profitability, tying up their capital, and increasing funding costs. Thus, banks with high NPL present potential risks to financial stability in the region (Canetti et al., 2017).

One of the things that banks face is the risk of unpaid credit that has been given or referred to as credit risk. Credit risk or default risk usually arises from various credits that fall into the category of NonPerforming Loans (NPL). According to the International Monetary Fund (IMF), loans can achieve NPL status in several ways, including: Principal and interest loan installments are at least 90 days due, and lenders no longer believe borrowers will comply with their debt obligations. In this case, the loan is written as bad debt in the lender's account book.

a. Interest payments for 90 days are capitalized, refinanced, or delayed due to changes in the loan agreement.

b. Principal and interest payments are less than 90 days late, and there's reason to doubt that borrowers won't pay the unpaid loan in full.

Based on the Regulation of the Otoritas Jasa Keuangan No. 3 Article 4 of 2018 the Bank under intensive supervision as referred to in Article 3 is stipulated by OJK for at least 1 (one) year from the date of the OJK notification letter. The period of intensive supervision as referred to in paragraph (1) can be extended by OJK at most 1 (one) time and a maximum of 1 (one) year only for Banks in intensive supervision that meet the criteria of one of which is the ratio of net non-problematic credit (net NPL) or net problem financing ratio (NPF net) of more than 5\% (five per cent) of total credit or total financing, And the solution is complex. If the bank's NPL is more than $5 \%$ it will affect the level of health of the bank. If banks can reduce the NPL ratio to below $5 \%$, then the potential profit obtained will be even greater, because banks save the necessary things to form a reserve of problematic credit losses 
or The Elimination of Productive Assets Allowance (PPAP).

\section{Return on Assets}

Bank profitability is the ability of a company in seeking profit or profit of a certain period (Rohmiati et al., 2019). To measure the level of profit of a bank, a profit ratio or profitability ratio is used. Analysis of ROA can be projected into the future to see the company's ability to generate profits against future assets. Return on Assets (ROA) to analyze or measure the level of business efficiency and profitability achieved (Rusnaini \& Ariyanto, 2019). Return on Assets (ROA) is an indicator of managerial efficiency that indicates management's ability to manage its assets for profit.

Return on Assets (ROA) provides information about the amount of income returned in return for any money invested in the form of assets. Return on Assets (ROA) indicates a business's capacity to generate profits using its assets. In some sectors, ROA is larger than others because the amount of capital invested in assets varies. Businesses that make products will often spend a lot of money on infrastructure and equipment. A company's operational efficiency is affected by the use of resources, which is seen in net profit margins. Success and failure are not always associated with high and low-profit margins. A business may have low margins but still, manage to create a high return on investment and assets. Return on Assets (ROA) adalah ukuran yang berguna untuk mengukur total profitabilitas dan efisiensi operasional bisnis karena menunjukkan bagaimana profitabilitas dan aktivitas operasional berinteraksi. Konsep ini berpendapat bahwa meningkatkan laba atas investasi, atau laba atas modal, baik dengan memperluas volume penjualan atau meningkatkan margin keuntungan, akan meningkatkan kinerja perusahaan (Panigrahi, 2021).

The relationship between NPL and Return on Assets (ROA) is that the lower the ROA level, the higher the NPL, and vice versa (Khan et al., 2020). (Messai \& Jouini, 2013) confirmed from his research that there is a negative relationship between ROA and NPL. As the ROA decreases, banks begin to invest in high-risk projects, and as a result, NPL levels increase. (Ghosh, 2015) indicates that there is a negative affiliation between ROA and NPL. (Dimitrios et al., 2016) investigated the various determinants of NPL in the euro banking system and concluded that ROA has a significant impact on NPLs. Based on previous arguments, we consider that:

H1. Return on Assets has a negative influence on Non-Performing Loans.

3. Income Diversification

Income diversification is a bank's strategy to obtain income not only from one source but several sources. Interest income is the main income of banking from traditional activities, namely lending, while in diversifying banking income looking for other new sources of income that are expected to be more stable, namely noninterest income (Widiasari \& Pangestuti, 2015).

Income diversification is non-interest income calculated by the remainder of the proportion of interest income difference and non-interest income to total operating income (Sianipar, 2015).

Revenue diversification is seen from an economic point of view, as an effort made by companies to minimize corporate risks to economic uncertainty. Revenue diversification is also considered a breakthrough for companies to benefit by utilizing their resources. Diversification itself is a form of business development by expanding existing market share or 
developing various products (Ayu Dian Aprilia, 2019).

According to Ashyari and Rokhim 2020, revenue diversification refers to the company's plan to expand its non-interest income so that the company's income does not only focus on traditional income, i.e. interest income. Diversification is a way to sustain risk and also reduce financial difficulties. Non-interest income can improve a bank's profitability and income stability, and another verifiable benefit is reducing a bank's credit risk.

Several studies have focused on examining the effect of investment diversification on non-performing loans . has researched what affects income diversification in the banking sector. These banks have better credit performance which indicates an inverse relationship between NPL and income diversification (Rachman et al., 2018). Showed that various banking factors that affect NPL in Indonesia include income diversification, bank capital, and other banking factors. Based on previous arguments, we consider that:

H2. Income diversification has a negative influence on non-performing loans.

4. Bank Capital

A bank's capital adequacy ratio is used to maintain and defuse financial risk. Under the supervision of bank capital, a bank's capital adequacy ratio affects the number of loans and the structure of loans, and the lack of bank liquidity will not only lead to individual liquidity risk of banks but also the rupture of systemic banking risks. Measuring the impact of bank capital levels on loan size is one of the most basic issues for verifying the relationship between the financial sector and the real economy and has been more concerned, but research into the impact of liquidity on loan size changes is relatively lacking.

Capital Adequacy Ratio (CAR) shows the adequacy of capital owned by banks to support assets that contain risk, such as credit provided (Damayanti \& Savitri, 2018) . Capital Adequacy Ratio (CAR) is a ratio that shows how far all bank assets that contain risk (credit, participation, securities, bills to other banks) are financed from their capital funds in addition to obtaining funds from sources outside the bank (Astrini et al., 2018). The higher the CAR, the better the bank's ability to bear the risk of any risky productive credit/ asset. If the value of CAR is high, then the bank can finance operational activities and make a considerable contribution to profitability (Khan et al., 2020).

The Capital Adequacy Ratio (CAR) measures the health level of a bank. This ratio represents the organization's ability to withstand abnormal losses and also demonstrates the strength and stability of the organization in times of crisis. Companies must maintain a minimum CAR for their survival. The ratio of capital to risk-weighted assets or Risk-Weighted Assets (ATMR) is used for its measurement (Khan et al., 2020) arguments, we consider that:

H3. Bank Capital has a negative influence on Non-Performing Loans

\section{Bank Efficiency}

In the banking sector, (Alber et al., 2019) stated that efficiency supports the success of macroeconomic policies implemented, which result in durable development, economic growth, and prosperity for society. The way to classify banking efficiency is distinguished between the two main types of banking efficiency first known as scale efficiency and first. Introduced by Farell which is the relationship between the average production cost per bank unit and volume, the second type being efficiency $\mathrm{X}$ and introduced by Leibenstein and represents deviation from the cost-effective borders 
that describe the lowest products. at a cost for a certain level of output (Yudistira, 2004)

(Alber et al., 2019) stated that efficiency supports the success of macroeconomic policies implemented, resulting in durable development, economic growth, and well-being for society. The definition of bank efficiency remains debatable among researchers. To determine what constitutes the efficiency of a bank, one must first decide the nature of the banking approach.

According to (Ekanayake \& Azeez, 2015) studied the factors affecting NPL in Sri Lanka's banking sector for the period between 1999 and 2012 and concluded that NPL had a negative correlation with bank size and bank efficiency (Benthem, 2017). examined the relationship between operating efficiency, capitalization, and NPL in commercial banks, and the results showed that operating efficiency increased higher NPL levels, which proposed that management behavior affects NPLs. (Rachman et al., 2018) state that operating efficiency does not affect NPL. So we propose that:

H4. Bank Efficiency has a negative influence on Non-Performing Loans.

\section{Method}

In this study, the authors used quantitative methods (Unaradjan, 2019). The study is based on panel data covering thirty-five conventional banks listed on the Indonesia Stock Exchange. The variables used in the model are calculated using the original data, the data used is secondary in the form of the annual financial statements of thirty-five Indonesian stateowned commercial banks listed on the Indonesia Stock Exchange in the period 20162020. The analysis method in this study uses a regression data panel with its analysis tool, IBM SPSS 25 software (Juliandi et al., 2018).

This study is based on data from a panel of conventional state-owned banks in Indonesia using purposive sampling, which is a sampling method by determining certain criteria. The banking population listed on the Indonesia Stock Exchange is 43 banks. Based on the large banking population, which serves as a research analysis unit from 2016 to 2020, which is 35 banks.

The use of panel data is the most suitable tool when the sample is amplified by cross-sectional and time-series data. The panel's data helps in identifying bank-specific factors and unknown observational differences between each bank (Ghosh, 2015). In this study, we considered the Indonesian banking sector. Non-Performing Loans (NPLs) are considered dependent variables and are measured as NPL ratios, while profitability, income diversification, capital and operating efficiency are considered independent variables.

Table 1

Research variables measurements

\begin{tabular}{llc}
\hline \multicolumn{1}{c}{ Variables } & \multicolumn{1}{c}{ Measurements } & Symbol \\
\hline Independent Variables & Net income to total assets & ROA \\
\hline Return on Assets & Capital divided by risk weighted asset & CAR \\
\hline $\begin{array}{l}\text { Bank Capital (Capital Adequacy } \\
\text { Ratio) }\end{array}$ & $\begin{array}{l}\text { Noninterest income divided by } \\
\text { total income }\end{array}$ & DIV \\
\hline Income Diversification & $\begin{array}{l}\text { Noninterest expense divided by noninterest } \\
\text { income. }\end{array}$ & EF \\
\hline Bank Efficiency & & \\
\hline Dependent Variables & &
\end{tabular}


\begin{tabular}{lll}
\hline Non-Performing Loans & NPLs to total loans & NPL
\end{tabular}

Source: Khan et al, 2020

\section{Data Panel Regression Model}

The research methods that correspond to the title of this study can be systematically spelled out the variable relationships as follows:

$\begin{array}{cl}\mathrm{NPL}_{\mathrm{it}}=\beta_{0}+\beta_{1} \mathrm{ROA}_{\mathrm{it}}+\beta_{2} \mathrm{CAP}_{\mathrm{it}}+\beta_{3} \mathrm{DIV}_{\mathrm{it}}+\beta_{4} \mathrm{EF}_{\mathrm{it}}+\mu_{\mathrm{it}} \\ \text { Where } & : \\ \text { NPL } & : \text { Non-Performing Loans } \\ \text { ROA } & : \text { Return on Assets } \\ \text { CAP } & : \text { Bank Capital } \\ \text { DIV } & : \text { Income Diversification } \\ \text { EF } & : \text { Bank Efficiency }\end{array}$

2. Normality Test

Normality test are used to determine whether or not data distribution is normal (Ainiyah et al., 2016). Good research data is data that has a normal distribution.
Normal distribution means the data has spread evenly so that it can represent the population. Abnormal data can be distinguished from skewness. If the data tends to lean to the left it is called positive skewness, if the data tends to lean to the right it is called negative skewness, and the data is said to be normal if the data is symmetrical. The way of normality test is by the One-Sample Kolmogorov Smirnov test method. The testing criteria are as follows:

- If the Signification value > 0.05, then the distribution data is normal.

- If the Signification value $\leq 0.05$, then the data does not distribute normally.

Table 2

Normality test

\begin{tabular}{cc}
\hline \multicolumn{2}{c}{ Kolmogorov - Smirnov } \\
\hline \multirow{2}{*}{ Unstandardized Residual } & Sig. \\
& 0.190 \\
\hline
\end{tabular}

Source: IBM SPSS 25

Based on the results of the normality test can be known the value of significance of $0.190>0.05$ then it can be concluded that the data is a normal distribution.

\section{Multicollinearity Test}

The multicollinearity test is used to determine the presence of high correlations between variables in multiple regression models. If there is a high correlation between independent variables, then the relationship between them of dependent variables will be disrupted. Thus, a good regression model should not be a correlation between independent variables, or perhaps multicollinearity but not highly correlated (Daoud, 2017). The multicollinearity test is conducted by looking at tolerance values and Variance Inflation Factor (VIF) values. Hypotheses performed in the multicollinearity test are:

- H0: VIF < 10 means there is no Multicollinearity.

- Ha: VIF > 10 means there is Multicollinearity.

- Collinearity Tolerance $>0.1$ then there is no multicollinearity

The results of multicollinearity testing in study respondents obtained that the VIF value is less than 10 so it can be stated that the model does not experience symptoms of multicollinearity.

Table 3

Multicollinearity test

$\begin{array}{llll}\text { Independent } & \text { Collinearity } & \text { VIF } & \text { Conclusion }\end{array}$


Factors Affecting Non-Performing Loans of Conventional Banking: Evidence in Indonesia Stock

\begin{tabular}{cccl}
\hline Variables & Tolerance & & \\
\hline ROA & 0.967 & 1.035 & Non-Multicollinearity \\
\hline CAR & 0.976 & 1.024 & Non-Multicollinearity \\
\hline DIV & 0.766 & 1.306 & Non-Multicollinearity \\
\hline EF & 0.762 & 1.312 & Non-Multicollinearity \\
\hline
\end{tabular}

Source: IBM SPSS 25

Based on the table above, it can be said that there is no multicollinearity because of the value of VIF $<10$. Known Collinearity Tolerance in ROA of $0.967>$ 0.1 and VIF value of $1.035<10.00$. Collinearity Tolerance in CAR of $0.976>$ 0.1 and VIF value of $1,024<10.00$. Collinearity Tolerance in DIV of $0.766>$ 0.1 and VIF value of $1,306<10.00$. Collinearity Tolerance at EF of $0.762>0.1$ and VIF value of $1,312<10.00$ so that it can be concluded that it is not Multicollinearity occurs.

\section{Heteroscedasticity Tests}

Heteroscedasticity tests are used to test their regression models of residual variance inequality from one observation to another. Regression formulas are obtained by assuming confounding variables (errors)

Table 4

Heteroscedasticity tests

\begin{tabular}{ccc}
\hline $\begin{array}{c}\text { Independent } \\
\text { Variables }\end{array}$ & Sig. & Conclusion \\
\hline ROA & 0.181 & Non-Heteroscedasticity \\
\hline CAR & 0.260 & Non-Heteroscedasticity \\
\hline DIV & 0.659 & Non-Heteroscedasticity \\
\hline EF & 0.309 & Non-Heteroscedasticity \\
\hline \multicolumn{2}{c}{ Source: IBM SPSS 25) }
\end{tabular}

Based on heteroscedasticity tests using Glejser tests it can be known that Sig. in ROA of $0.181>0.05$. Sig. in CAR of $0.260>0.05$. Sig. at DIV of $0.659>$ 0.05. Sig. at EF of $0.309>0.05$, it can be concluded that there is no problem of heteroscedasticity in regression models.

\section{F Test}

The $\mathrm{F}$ test is used to find out whether independent variables jointly have constant residual variance (same range of errors). Heteroscedasticity occurs if there is a non-constant residual variance. The regression model becomes good if there is no heteroscedasticity (Ainiyah et al., 2016). A regression model that either represents homoscedasticity or no heteroscedasticity occurs.

This study to test the absence of heteroscedasticity using the Glejser test, where the basis of the intake out is:

- Sig. $<0.05$ then there are symptoms of heteroscedasticity in regression models

- Sig. > 0.05 then there are no symptoms of heteroscedasticity in regression models (simultaneously) affect or do not affect dependent variables and to find out whether the model used in panel data regression is appropriate and feasible to use. The basis of decision-making $\mathrm{F}$ test are:

$-\mathrm{H} 0$ is rejected if Sig. $<0.05$ or F calculates the $>\mathrm{F}$ of the table, then there is the influence of variable $\mathrm{X}$ simultaneously on variable $\mathrm{Y}$

- H0 accepted when Sig. > 0.05 or F calculates $<\mathrm{F}$ table, then there is no 
simultaneous effect of variable $\mathrm{X}$ on $\quad=\mathrm{F}(4 ; 31)=2.68$ then obtained t table of variable $\mathrm{Y}$

In this study to obtain $t$ tables used 2,042. From the results of regression obtained the following results:

formulas with $\mathrm{F}$ table $=\mathrm{F}(\mathrm{k} ; \mathrm{n}-\mathrm{k}))$ or $\mathrm{F}$ table

Table 5

F test

\begin{tabular}{ccc}
\hline F-statistics & A & Description \\
\hline $\mathbf{3 . 4 7 2}$ & 0.05 & H0 rejected \\
\hline \multicolumn{3}{c}{ Source: IBM SPSS 25}
\end{tabular}

Based on the results of the test $\mathrm{F}$ can be known the value of significance for the influence of all independent variables simultaneously on dependent variables is $0.019<0.05$ and the value $\mathrm{F}$ calculates 3.472 $>2.68$ so it can be concluded that $\mathrm{HO}$ is dotilak and $\mathrm{Ha}$ is accepted. This means that there is simultaneous influence of ROA, CAR, DIV and EF on NPL.

\section{Result and Discussion}

\section{A. Result}

\section{Descriptive Statistics Analysis}

Descriptive statistics describe the characteristics of data in a short form, i.e. looking at the results of the minimum, maximum, mean, and standard deviation values of each variable. The minimum value indicates the lowest value of the variable, while the maximum value indicates the highest value of each variable. The mean value describes the average value of each research variable. Standard deviation is the distribution of research data that shows the data is heterogeneous or homogeneous that is volatile. The following are descriptive statistical results from the research variables used:

Table 6

Descriptive statistics

\begin{tabular}{ccc}
\hline Variables & Observation & Min \\
\hline NPL & 175 & 0.0020 \\
ROA & 175 & -0.0747 \\
CAR & 175 & 0.0153 \\
DIV & 175 & 0.0169 \\
EF & 175 & 0.0029 \\
\hline \multicolumn{4}{c}{ Source: IBM SPSS 25 }
\end{tabular}

Table 7

Descriptive statistics

\begin{tabular}{ccc}
\hline Variables & Observation & Min \\
\hline NPL & 175 & 0.1575 \\
ROA & 175 & 0.1589 \\
CAR & 175 & 14.5300 \\
DIV & 175 & 0.8608 \\
EF & 175 & 1.1931 \\
\hline \multicolumn{3}{c}{ Source: IBM SPSS 25 }
\end{tabular}

Table 8

Descriptive statistics

\begin{tabular}{ccc}
\hline Variables & Observation & Min \\
\hline
\end{tabular}




\begin{tabular}{ccc}
\hline NPL & 175 & 0.0338 \\
ROA & 175 & 0.0171 \\
CAR & 175 & 0.4022 \\
DIV & 175 & 0.2178 \\
EF & 175 & 0.0856 \\
\hline \multicolumn{3}{c}{ Source: IBM SPSS 25 }
\end{tabular}

Table 9

Descriptive statistics

\begin{tabular}{ccc}
\hline Variables & Observation & Min \\
\hline NPL & 175 & 0.0212 \\
ROA & 175 & 0.0254 \\
CAR & 175 & 1.5308 \\
DIV & 175 & 0.1420 \\
EF & 175 & 0.1404 \\
\hline
\end{tabular}

Source: IBM SPSS 25

\section{Description}

1) Non-Performing Loans has an average value of 0.0338 with a standard deviation value of 0.0212 . The maximum value of Non-Performing Loans is owned by PT Bank Yudha Bakti, Tbk., with a value of 0.1575 in 2018, while the minimum value of Non-Performing Loans by PT Bank Ganesha, Tbk., with a value of 0.0020 in 2017.

2) Return on Assets has an average value of 0.0171 with a standard deviation value of 0.0254 . The maximum value of Return on Assets is owned by PT Bank Artos Indonesia, Tbk., with a value of 0.1589 in 2019, while the one with a minimum return on assets by PT Bank MNC International, Tbk., with a value of -0.0747 in 2017.

3) Capital Adequacy Ratio has an average value of 0.4022 with a standard deviation value of 1.5308. The maximum capital Adequacy ratio is owned by PT Bank J'Trust Indonesia, Tbk., with a value of 14.5300 in 2019 , while the minimum capital Adequacy ratio by PT Bank Woori Saudara, Tbk., with a value of 0.0153 in 2016 .
4) Income Diversification has an average value of 0.2178 with a standard deviation value of 0.1420 . The maximum value of Income Diversification is owned by PT QNB Indonesia, Tbk., with a value of 0.8608 in 2018, while the minimum income diversification value by PT Bank Mayapada Internasional, Tbk., with a value of 0.0169 in 2016.

5) Bank Efficiency has an average value of 0.0856 with a standard deviation value of 0.1404. The maximum value of Bank Efficiency is owned by PT Bank Ina Perdana, Tbk., with a value of 1.1931 in 2020, while the minimum value of Bank Efficiency by PT Bank Mayapada Internasional, Tbk., with a value of 0.0029 in 201.

\section{T Test Result}

The $t$ test is used to test how the influence of each independent variable i.e. ROA, CAR, DIV, and EF against the dependent variable i.e. NPL. This test can be done by juxtaposing $t$ count with $\mathrm{t}$ table or by looking at the significance column on each t count, the $t$ test process is identical to the Stepwise method test. 

Table 10

T test

\begin{tabular}{cccc}
\hline Independent & \multicolumn{3}{c}{ Dependent Variable } \\
\cline { 2 - 4 } Variables & \multicolumn{3}{c}{ Non-Performing Loans } \\
\cline { 2 - 4 } & Coefficient & Sig. & Conclusion \\
\hline Constanta & 0.24 & & \\
\hline ROA & -0.515 & 0.030 & Significant Negative \\
\hline CAR & -0.004 & 0.019 & Significant Negative \\
\hline DIV & 0.045 & 0.055 & Has No Effect \\
\hline EF & -0.001 & 0.038 & Significant Negative \\
\hline
\end{tabular}

(Source: IBM SPSS 25)

Based on the $\mathrm{T}$ Test in the table above, the results can be spelled out as follows:

1. Return on Assets showing a significance value of $0.030<0.05$ with a coefficient of -0.515. That is, Return on Assets negatively and significantly affects NonPerforming Loans.

2. Capital Adequacy Ratio shows a significance value of $0.019<0.05$ with a coefficient of -0.004 . That is, the Capital Adequacy Ratio has a negative and significant influence on Non-Performing Loans.

3. Income Diversification shows a significance value of $0.055>0.05$ with a coefficient of 0.045 . That is, Income Diversification does not influence NonPerforming Loans.

4. Bank Efficiency shows a significance value of $0.038<0.05$ with a coefficient of -0.001. That is, Bank Efficiency has a negative and significant effect on NonPerforming Loans.

\section{B. Discussion}

Based on hypothesis testing with the $\mathrm{T}$ Test, the influence of each independent variable on the dependent variable can be interpreted as follows:

\section{Return on Assets}

Based on hypothesis tests obtained in this study, it can be known that Return on Assets has a negative influence on Non-Performing Loans. This can be interpreted that the small amount of profit seen from the total assets will affect the risk of banking credit. The results of this study are in line with research conducted by (Khan et al., 2020) that the relationship between NPL and ROA is the lower the level of ROA, the higher the NPL and vice versa (Khan et al., 2020), (Anwar \& Sunaenah, 2016) confirmed from his research that there is a negative relationship between ROA and NPL. As the ROA decreases, banks begin to invest in high-risk projects, and as a result, NPL levels increase. (Makri et al., 2014) indicate that there is a negative affiliation between ROA and NPL, while (Khan et al., 2020) states that there is a positive relationship between ROA and NPL. (Dimitrios et al., 2016) investigated the various determinants of NPL in the euro banking system and concluded that ROA had a significant impact on NPL. This finding indicates that the larger the ROA of a bank, the greater the position of the bank in terms of asset use. Return on Assets (ROA) compares the value of a business asset with the profits it generates over a period of time. Return on Assets (ROA) is a tool used by companies to determine how effectively a company uses its resources to make a profit without pressuring the financial manager to make even more profit from its credit 
distribution. Thus leading to higher profitability has proven that banking financial managers can monitor the quality of credit channelled and manage problematic credit.

\section{Income Diversification}

Based on the hypothesis tests obtained in this study, it can be known that Income Diversification does not influence Non-Performing Loans. This can be interpreted that a large amount of income diversification will not affect the credit risk of banking. The results of this study are in line with research conducted by (Prawira \& Wiryono, 2020) which states that there is no relationship between income diversification and NPL levels (Kurniawan \& Siswanto, 2021). stated that income diversification does not correlate with NPL. The level of income diversification does not affect the increase or decrease in the bank's performance in maintaining risk and also reduces financial difficulties. This sulks at the descriptive statistical results in this study which has an average income diversification of $21.78 \%$ and a maximum value of $86.07 \%$. This indicates that banks that have a high-income diversification value can be said to be able to attract depositors to keep their money in the bank so that it can be an acceptance that if more and more can increase loans to debtors without increasing the number of problematic loans.

\section{Bank Capital}

Based on hypothesis tests obtained in this study, it can be known that the Capital Adequacy Ratio has a negative influence on Non-Performing Loans. This can be interpreted that the high capital adequacy ratio being used to maintain and relieve financial risk, one of which is the risk of debtor default. The bank's capital effect on the NPL is in the opposite direction. On the one hand, incentives and encouraging low-capital bank managers tend to engage in high-risk investments and provide loans issued without proper credit ratings and monitoring. The results of this study are in line with the research of (Siswanto et al., 2019). The state that the increase in loan defaults occurred indicates a negative relationship between bank capital and NPL. Based on research conducted by (El-Maude et al., 2017), it was found that CAR has a negative effect on the ups and downs of NPL. The results of this study are in line with research conducted by (Dewi $\&$ Suhartono, 2021) which showed a negative correlation between CAR and NPL. In addition, (Khan et al., 2020) stated that regarding banking factors, NPL and CAR have a negative relationship in the banking sector. These findings indicate that the capital held by the bank can bear all productive assets that contain risk, such as credit risk. Higher capital adequacy can reduce the risk level of debtor default. Banks that have a higher capital adequacy ratio indicate the existence of better credit management so that the bank is able to minimize the risk of default.

\section{Bank Efficiency}

Based on the hypothesis tests obtained in this study, it can be known that Bank Efficiency has a negative influence on Non-Performing Loans. This can be interpreted that the high level of efficiency in banks can reduce the risk of default on bank loans. The results of this study are in line with the research (Khan et al., 2020) which states that a decrease in the cost efficiency of commercial banks will 
affect the small risk of future default. This is faced by managers who are unable to control the operational and management costs of the loan portfolio. (Kurniawan \& Siswanto, 2021) examined the relationship between operational efficiency, capitalization, and NPL in commercial banks, the results showed that operational efficiency suppressed higher NPL levels. (Ekanayake \& Azeez, 2015) studied the factors affecting NPL in Sri Lanka's banking sector for the period between 1999 and 2012 and concluded that NPL had a negative correlation with bank size and bank efficiency. There is a correlation between NPL levels in private banks and their banking factors such as capitalization, bank efficiency, and profitability. The findings suggest that bank efficiency leads to low NPL levels, suggesting that management influences NPL levels. (Benthem, 2017) examined the relationship between operating efficiency, capitalization, and NPL in commercial banks, and the results showed that operating efficiency increased higher NPL levels, which proposed that management behaviour affect NPLs. This finding indicates that at a time when the bank's efficiency level increases, the bank will pressure its financial managers into making even more profit through the distribution of its credit because the bank is doing all its business activities at a relatively low cost, it can be said that the bank efficiently does its job.

\section{Conclusions}

This research was conducted to analyze the influence between Return on Assets (ROA), Income Diversification, Bank Capital as measured by Capital Adequacy Ratio (CAR), and Bank Efficiency on NonPerforming Loans (NPL) on banking sector companies listed on the Indonesia Stock Exchange (IDX) with a sample number of 35 companies in 2016-2020. The conclusions of the results of the study that can be taken are as follows Return on Assets, Bank Capital, and Bank Efficiency have a negative influence on Non-Performing Loans while Income Diversification does not influence NonPerforming Loans.

\section{References}

Ainiyah, N., Deliar, A., \& Virtriana, R. (2016). The classical assumption test to driving factors of land cover change in the development region of northern part of west Java. The International Archives of Photogrammetry, Remote Sensing and Spatial Information Sciences, 41, 205.Google Scholar

Alber, N., Elmofty, M., Walied, I., \& Sami, R. (2019). Banking Efficiency: Concepts, Drivers, Measures, Literature and Conceptual Model. Drivers, Measures, Literature and Conceptual Model (January 5, 2019). Google Scholar

Anwar, C. J., \& Sunaenah, S. (2016). Pengaruh Roa Dan Car Terhadap Kredit Macet (Npl) Pada Bank Umum Di Indonesia. Jurnal Ekonomi-Qu, 6(2). Google Scholar

Astrini, K. S., Suwendra, I. W., \& Suwarna, I. K. (2018). Pengaruh CAR, LDR, dan Bank Size terhadap NPL pada Lembaga Perbankan yang Terdaftar di Bursa Efek Indonesia. Jurnal Manajemen Indonesia, 6(1), 9-16. Google Scholar

Ayu Dian Aprilia, A. D. (2019). Pengaruh Diversifikasi, Leverage Dan Profitabilitas Terhadap Nilai Perusahaan. Jurnal Administrasi Bisnis, 73(2). http://administrasibisnis.studentjournal.u b.ac.id/index.php/jab/article/view/2933 Google Scholar 
Benthem, C. S. (2017). The relation among non-performing loans, operating efficiency, and capitalization in commercial banking. University of Twente. Google Scholar

Canetti, E., Beaton, K., Dowling, T., Kovtun, D., Loyola, F., Myrvoda, A., Okwuokei, J. C., Ötker, İ., \& Turunen, J. (2017). Problem Loans in the Caribbean: Determinants, Impact, and Strategies for Resolution. In Unleashing Growth and Strengthening Resilience in the Caribbean. International Monetary Fund. Google Scholar

Damayanti, P., \& Savitri, D. A. M. (2018). Analisis Pengaruh Ukuran (Size), Capital Adequacy Ratio (Car), Pertumbuhan Deposit, Loan to Deposit Rasio (Ldr), Terhadap Profitabilitas Perbankan Go Public Di Indonesiatahun 2005-2009. Jurnal Ilmu Manajemen Dan Akuntansi Terapan (JIMAT), 3(2), 45-54. Google Scholar

Daoud, J. I. (2017). Multicollinearity and regression analysis. Journal of Physics: Conference Series, 949(1), 12009. Google Scholar

Dewi, A. T., \& Suhartono, S. (2021). The Effect of Internal and External Factors of Non-Performing Loan at National Private Commercial Banks (Go Public) in Indonesia from 2016-2020. Google Scholar

Dimitrios, A., Helen, L., \& Mike, T. (2016). Determinants of non-performing loans: Evidence from Euro-area countries. Finance Research Letters, 18, 116-119. Google Scholar

Ekanayake, E., \& Azeez, A. A. (2015). Determinants of non-performing loans in licensed commercial banks: Evidence from Sri Lanka. Asian Economic and Financial Review, 5(6), 868. Google Scholar

El-Maude, J. G., Abdul-Rahman, A., \&
Ibrahim, M. (2017). Determinants of nonperforming loans in Nigeria's deposit money banks. Archives of Business Research, 5(1), 74-88. Google Scholar

Ghosh, A. (2015). Banking-industry specific and regional economic determinants of non-performing loans: Evidence from US states. Journal of Financial Stability, 20, 93-104. Google Scholar

Ivanović, M. (2016). Determinants of credit growth: The case of Montenegro. Journal of Central Banking Theory and Practice, 5(2), 101-118. Google Scholar

Juliandi, A., Manurung, S., \& Satriawan, B. (2018). Mengolah data penelitian bisnis dengan SPSS. Lembaga Penelitian dan Penulisan Ilmiah AQLI. Google Scholar

Khan, M. A., Siddique, A., \& Sarwar, Z. (2020). Determinants of non-performing loans in the banking sector in developing state. Asian Journal of Accounting Research. Google Scholar

Kurniawan, D. T., \& Siswanto, E. (2021). The Impact of Income Diversification and Non-Interest Income Diversification on Indonesian Bank Performance, 20122017. Asia-Pacific Research in Social Sciences and Humanities Universitas Indonesia Conference (APRISH 2019), 540-546. Google Scholar

Kusaly, D. A. V, Tommy, P., \& Maramis, J. (2017). Pengaruh Kebijakan Pemberian Kredit Terhadap Non Performing Loan Dan Harga Saham Bank Di Bursa Efek Indonesia (BEI). Jurnal EMBA: Jurnal Riset Ekonomi, Manajemen, Bisnis Dan Akuntansi, 5(2). Google Scholar

Makri, V., Tsagkanos, A., \& Bellas, A. (2014). Determinants of non-performing loans: The case of Eurozone. Panoeconomicus, 61(2), 193-206. Google Scholar

Messai, A. S., \& Jouini, F. (2013). Micro and macro determinants of non-performing loans. International Journal of Economics and Financial Issues, 3(4), 


\section{Google Scholar}

Panigrahi, C. M. A. (2021). Financial analysis by return on equity (ROE) and return on asset (ROA)-A comparative study of HUL and ITC. Panigrahi AK, Vachhani $K$, Financial Analysis by Return on Equity (ROE) and Return on Asset (ROA)-A Comparative Study of HUL and ITC. J Manag Res Anal, 8(3), 131-138. Google Scholar

Prawira, R., \& Wiryono, S. K. (2020). Determinants of non-performing loans in state-owned banks. Jurnal Akuntansi Dan Auditing Indonesia, 24(2), 159-166. Google Scholar

Rachman, R. A., Kadarusman, Y. B., Anggriono, K., \& Setiadi, R. (2018). Bank-specific factors affecting nonperforming loans in developing countries: Case study of Indonesia. The Journal of Asian Finance, Economics, and Business, 5(2), 35-42. Google Scholar

Rohmiati, E., Winarni, W., \& Soebroto, N. W. (2019). Analisis Pengaruh Bopo, Npl, Nim, Dan Ldr Terhadap Profitabilitas Pada Bank Umum Di Indonesia Periode 2012-2017. Keunis, 7(1), 34-48. Google Scholar

Rusnaini, S., \& Ariyanto, M. (2019). non performing loan (npl) dan return on asset (roa) di koperasi nusantara muara bungo. Jurnal Ilmiah MEA (Manajemen, Ekonomi, \& Akuntansi), 3(1), 1-18. Google Scholar
Sianipar, A. S. (2015). Pengaruh diversifikasi pendapatan terhadap kinerja bank. Jurnal Siasat Bisnis, 19(1), 27-35. Google Scholar

Siswanto, S., Supriyanto, A., Ni'mah, U., Asnawi, N., \& Wekke, I. (2019). Does a workload influence the performance of bank employees? Management Science Letters, 9(5), 639-650. Google Scholar

Unaradjan, D. D. (2019). Metode penelitian kuantitatif. Penerbit Unika Atma Jaya Jakarta. Google Scholar

Vouldis, A. T., \& Louzis, D. P. (2018). Leading indicators of non-performing loans in Greece: the information content of macro-, micro-and bank-specific variables. Empirical Economics, 54(3), 1187-1214. Google Scholar

Widiasari, F. W., \& Pangestuti, I. R. D. (2015). Pengaruh Struktur Pasar, Kompetisi, Diversifikasi, Kapitalisasi, Risiko Kredit, Dan Size Terhadap Profitabilitas Bank (Studi pada Bank Umum Konvensional di Indonesia Periode 2009-2013). Fakultas Ekonomika dan Bisnis.

Yudistira, D. (2004). Efficiency in Islamic banking: an empirical analysis of eighteen banks. Islamic Economic Studies, 12(1). Google Scholar

\section{Copyright holder :}

Hanna Khoirunisa, Cyntia Monalisa Hutauruk, Susy Muchtar 2022.

First publication right :

Jurnal Syntax Transformation

This article is licensed under:

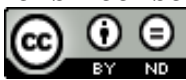

